\title{
Transgenic rescue of phenotypic deficits in a mouse model of alternating hemiplegia of childhood
}

\author{
Greer S. Kirshenbaum ${ }^{1,2}$ - James Dachtler ${ }^{3}$ John C. Roder ${ }^{1,2} \cdot$ Steven J. Clapcote ${ }^{3}$
}

Received: 25 July 2015 / Accepted: 16 September 2015 /Published online: 13 October 2015

(C) The Author(s) 2015. This article is published with open access at Springerlink.com

\begin{abstract}
Missense mutations in ATP $1 A 3$ encoding $\mathrm{Na}^{+}, \mathrm{K}^{+}$ATPase $\alpha 3$ are the primary cause of alternating hemiplegia of childhood (AHC). Most ATP1A3 mutations in AHC lie within a cluster in or near transmembrane $\alpha$-helix TM6, including $\mathrm{I} 810 \mathrm{~N}$ that is also found in the Myshkin mouse model of AHC. These mutations all substantially reduce $\mathrm{Na}^{+}, \mathrm{K}^{+}$-ATPase $\alpha 3$ activity. Herein, we show that Myshkin mice carrying a wildtype Atpla3 transgene that confers a $16 \%$ increase in brainspecific total $\mathrm{Na}^{+}, \mathrm{K}^{+}$-ATPase activity show significant phenotypic improvements compared with non-transgenic Myshkin mice. Interventions to increase the activity of wild-type $\mathrm{Na}^{+}$, $\mathrm{K}^{+}$-ATPase $\alpha 3$ in AHC patients should be investigated further.
\end{abstract}

Keywords Alternating hemiplegia $\cdot$ Transgenic rescue . $\mathrm{Na}^{+}, \mathrm{K}^{+}$-ATPase $\alpha 3 \cdot$ Atpla $3 \cdot$ Mice

Electronic supplementary material The online version of this article (doi:10.1007/s10048-015-0461-1) contains supplementary material, which is available to authorized users.

Steven J. Clapcote

s.j.clapcote@leeds.ac.uk

1 Lunenfeld-Tanenbaum Research Institute, Mount Sinai Hospital, University Avenue, Toronto, ON M5G 1X5, Canada

2 Institute of Medical Science, University of Toronto, Toronto, ON M5S 1A8, Canada

3 School of Biomedical Sciences, Garstang Building, University of Leeds, Leeds LS2 9JT, UK

\section{Introduction}

Alternating hemiplegia of childhood (AHC; OMIM: 614820) is a rare neurodevelopmental disorder which manifests as episodic hemiplegia starting in the first 18 months of life, with a spectrum of persistent motor, movement, and cognitive deficits that become progressively more apparent with age $[1,2]$. Approximately half of AHC patients present with epilepsy; the seizures are predominantly partial but may manifest as status epilepticus requiring urgent medical attention [2]. Heterozygous missense mutations of the ATP1A3 gene, encoding the $\mathrm{Na}^{+}, \mathrm{K}^{+}$-ATPase $\alpha 3$ subunit, have been identified as the primary cause of AHC [3]. Belonging to the type II P-type ATPase family of proteins that have a transmembrane domain permeable to specific ions, $\mathrm{Na}^{+}, \mathrm{K}^{+}$-ATPases are membranebound transporters that harness the energy of ATP hydrolysis to pump three $\mathrm{Na}^{+}$ions out of the cell in exchange for two $\mathrm{K}^{+}$ ions moving inward [4]. The $\alpha 3$ subunit has ten transmembrane $\alpha$-helices which contain the $\mathrm{Na}^{+}$- and $\mathrm{K}^{+}$-binding sites and the cytoplasmic domains involved in ATP hydrolysis [4]. Most ATP1A3 mutations in AHC patients lie within a cluster in or near transmembrane $\alpha$-helix TM6 [5], including three affecting the isoleucine at position 810: I810F [5], I810N [6], and I810S [7]. Flunarizine, a non-selective calcium entry blocker targeting voltage-dependent calcium channels, reduces the severity, duration, or frequency of hemiplegic attacks in some patients [6], while two AHC patients - positive for T804I and D923N, respectively - have shown marked improvements in symptoms when treated with a ketogenic diet $[8,9]$. However, the complexity and severity of AHC make it imperative that new therapeutic options specifically targeting $\mathrm{Na}^{+}, \mathrm{K}^{+}$-ATPase $\alpha 3$ be explored.

To better understand the consequences of $\mathrm{Na}^{+}, \mathrm{K}^{+}$-ATPase $\alpha 3$ dysfunction and explore potential therapeutic approaches for this disorder, investigations in animal models harboring 
the same mutations as human patients are needed. Heterozygous Myshkin (Atpla3 ${ }^{M y k /+} ;$ Myk/+) mutant mice have an I810N amino acid substitution in transmembrane $\alpha$-helix TM6 identical to that present in AHC $[6,10]$. A 12-year-old Chinese male with the I810N mutation is reported to have AHC with developmental delay and epilepsy [6]. Myk/+ mice often show hypokinesia upon arousal and move with a paretic, tremulous gait that becomes transiently more severe after stress (Supplementary Video 1 and 2) [11]. Myk/+ mice have not, however, been observed by video monitoring over $24 \mathrm{~h}$, so it is not known whether they exhibit frank hemiparesis or hemiplegia when left undisturbed in the home cage. Other phenotypic abnormalities include decreased body mass, neuronal hyperexcitability, increased susceptibility to epileptic seizures, motor dysfunction, and cognitive impairment [10-12]. Molecular modeling of I810N has shown that it brings about severe structural effects on $\mathrm{Na}^{+}, \mathrm{K}^{+}$-ATPase $\alpha 3$, including the capacity for efficient $\mathrm{K}^{+}$movement along the $\mathrm{K}^{+}$ access pathway [11]

Missense mutations in AHC patients and Myk/+ mice all substantially reduce $\mathrm{Na}^{+}, \mathrm{K}^{+}$-ATPase $\alpha 3$ activity $[8,13]$. I $810 \mathrm{~N}$ in $M y k /+$ mice is functionally a null allele of Atpla3 that encodes a normally expressed, but catalytically inactive, $\mathrm{Na}^{+}, \mathrm{K}^{+}$-ATPase $\alpha 3$ enzyme [8]. Brain-specific total $\mathrm{Na}^{+}, \mathrm{K}^{+}$ATPase activity (contributed by $\alpha 1, \alpha 2$, and $\alpha 3$ isoforms) is $64 \%$ of wild-type levels in $M y k /+$ mice [14], but $84 \%$ of wildtype levels in heterozygous Atpla $3^{\mathrm{tm} 1 \mathrm{Ling} /+}$ mice that have a point mutation in intron 4 of the Atpla3 gene [14, 15]. Since Atpla $3^{\text {tmlLing/+ }}$ mice do not have visible neurological defects nor restricted growth [15], we hypothesized that increasing brain $\mathrm{Na}^{+}, \mathrm{K}^{+}$-ATPase activity from $64 \%$ to closer to $84 \%$ of wild-type levels would mitigate disease phenotype severity in $M y k /+$ mice.

Transgenic (Tg)-Atp $1 a 3^{1 \text { Stcl }}$ mice carry a bacterial artificial chromosome (BAC) transgene of Mus musculus molossinus origin (MSMg01-344N17) that contains the wild-type Atpla3 gene and its promoter [10]. The Tg-Atpla $3^{1 \mathrm{Stcl}}$ transgene was previously shown to increase $\mathrm{Na}^{+}, \mathrm{K}^{+}$-ATPase $\alpha 3$ protein expression by $58 \%$ and brain $\mathrm{Na}^{+}, \mathrm{K}^{+}$-ATPase activity from 64 to $80 \%$ of wild-type levels in $M y k /+$ mice [10]. The purpose of the present study was to determine whether this increase in brain $\mathrm{Na}^{+}, \mathrm{K}^{+}$-ATPase activity, to a level comparable with that of Atpla $3^{\text {tmlLing/+ }}$ mice ( $\sim 80 \%$ of wild-type), would have remedial effects in phenotypic tests in which $M y k /+$ mice show clear deficiencies.

\section{Materials and methods}

\section{Subjects}

$M y k /+$ mice were genotyped by the presence of an EcoO109I (New England BioLabs) restriction site using PCR primers F,
5'-CTG CCG GAA ATA CAA TAC TGA-3' and R, 5'-ATA AAT ACC CCA CCA CTG AGC-3'. Hemizygous TgAtpla $3^{1 \mathrm{Stcl} /+}(\mathrm{Tg} /+)$ mice were genotyped using PCR primers F, 5'-TGA CAT TGT AGG ACT ATA TTG C-3' and R, 5'GTT AAA GGT GTG AGG CAC AGA-3' spanning the T7 vector-insert boundary. Both lines were backcrossed for 11 $(\mathrm{Tg} /+)$ or 21 generations $(M y k /+)$ to the $\mathrm{C} 57 \mathrm{BL} / 6 \mathrm{NCr}$ strain (NCI-Frederick). $M y k /+$ males were crossed with $\mathrm{Tg} /+$ females to yield wild-type (+/+), Myk/+, Tg/+, and $M y k /+/ \mathrm{Tg}$ $\left(\mathrm{I} 810 \mathrm{~N}+\mathrm{Tg}-\right.$ Atpla $\left.3^{1 \mathrm{Stcl}}\right)$ littermates. Mice were weaned at 4 weeks of age and grouped housed (two to five mice/cage) with same-sex littermates. Supplementary food pellets were provided on the cage floor for the first 2 weeks postweaning because of the small size of $M y k /+$ mice. Mice were weighed at 4 and 8 weeks of age using a Scout Pro portable balance (Ohaus).

\section{Behavioral procedures}

$M y k /+,+/+, \mathrm{Tg} /+$, and $M y k /+/ \mathrm{Tg}$ littermates ( $n=12 /$ genotype) were tested at 8-14 weeks of age. Males and females were included in balanced numbers. Subjects were handled daily for $5 \mathrm{~min} /$ day for 7 days prior to behavioral testing, which was conducted during the light phase (0900-1700 h). Prior to experiments, subjects were left undisturbed in the testing environment for $30 \mathrm{~min}$ to allow for acclimation. A solution of $70 \%$ ethanol was used to clean surfaces and equipment between subjects. The order of tests, with a rest period of 35 days between each test, was as follows: body weight $\rightarrow$ balance beam $\rightarrow$ Morris water maze $\rightarrow$ fear conditioning.

\section{Balance beam}

Mice were given five training trials on a $90-\mathrm{cm}-$ long, $18-\mathrm{mm}-$ wide beam elevated $50 \mathrm{~cm}$ above a padded base. A $60-\mathrm{W}$ lamp at the start platform served as an aversive stimulus, whereas the opposite end of the beam entered a darkened escape box baited with food pellets. Performance on the beam was quantified in a test trial given $24 \mathrm{~h}$ after training by measuring the time that it took for the mouse to traverse the beam and the number of hind foot slips that occurred in the process.

\section{Visible platform water maze}

The water maze consisted of a cylindrical tub of ivory-colored acrylic sheet (117-cm diameter; 30-cm depth) that was filled with water $\left(26 \pm 1^{\circ} \mathrm{C}\right.$ temperature $)$ to $11 \mathrm{~cm}$ below the rim. A circular platform (10-cm diameter) made of transparent acrylic sheet was submerged $1 \mathrm{~cm}$ below the water surface at the center of the pool. The platform location was indicated by a high-contrast striped marker rising $13 \mathrm{~cm}$ above the water surface. Each subject was given four training trials. At the start of each trial, the mouse was placed by the tail into the water, 
immediately facing the perimeter, at one of the cardinal compass points (north, south, east, or west), and then was allowed a maximal time of $90 \mathrm{~s}$ to locate the platform. Finding the platform was defined as staying on it for at least $2 \mathrm{~s}$. A closed-circuit television camera was mounted onto the ceiling directly above the center of the pool to convey subject swimming trajectories and parameters to an electronic image analyzer (HVS Image), which extracted and stored the X-Y coordinates of the subject's position at sample points every $0.01 \mathrm{~s}$. Behavioral variables were quantified with the aid of HVS Water 2020 (HVS Image).

\section{Contextual fear conditioning}

Experiments were conducted in a fear-conditioning chamber (MED Associates; $25-\mathrm{cm}$ height $\times 30-\mathrm{cm}$ width $\times 25-\mathrm{cm}$ length) with a removable grid floor of 36 stainless steel rods (3.2-mm diameter, $4.7 \mathrm{~mm}$ apart) connected to a constant current shock generator. FreezeFrame 1.6e software (Actimetrics) administered foot shocks, recorded video images of the chamber, and monitored the activity of subjects throughout the procedure. For the training phase, mice were placed in the chamber for $2 \mathrm{~min} 28 \mathrm{~s}$, after which, they received a continuous scrambled foot shock of $0.75 \mathrm{~mA}$ for $2 \mathrm{~s}$ and then remained in the chamber for an additional $30 \mathrm{~s}$ before being returned to their home cage. Twenty-four hours following training, mice were returned to the fear-conditioning chamber to evaluate their contextual fear memory. Freezing to the context was recorded at 0.25 -s intervals using FreezeFrame for $3 \mathrm{~min}$, and then, mice were returned to their home cage.

\section{Statistical analysis}

All statistics were calculated by STATISTICA (StatSoft). Data were subjected to analysis of variance (ANOVA) with Atpla3 genotype, Tg genotype, and sex as between-subjects factors. No sex by Atpla3 genotype or sex by Tg genotype interaction was observed for any variable measured. When ANOVA detected statistically significant main effects, pairwise differences were evaluated using Tukey-Kramer post hoc multiple comparison tests, with significance set at $p<0.05$. Student's paired $t$ test was used to compare baseline freezing with contextual freezing. All values reported in the figures are expressed as mean \pm standard error of the mean (SEM).

\section{Results and discussion}

\section{Body weight}

AHC patients tend to be of short stature and low weight [2, 16]. We measured the body weight of mice aged 4 weeks, when they were weaned, and aged 8 weeks, when behavioral testing commenced. At both ages, the body weight of $M y k /+$ mice was significantly less than that of the other genotypes (Fig. 1). Relative to $+/+$ mice, the 4-week weight of $M y k /+$ mice was less by $20.4 \pm 5.1 \%$ in females and by $20.6 \pm 6.1 \%$ in males. By 8 weeks, body weight was less by $10.8 \pm 3.3 \%$ in $M y k /+$ females and by $18.6 \pm 3.3 \%$ in $M y k /+$ males, and a sex by Atpla3 genotype interaction approaching significance $(F(1,42)=3.66, p=0.0626)$ was observed. $M y k /+/ \mathrm{Tg}$ mice did not show any significant deficits in body weight, as confirmed by the significant Atpla3 genotype by Tg genotype interactions observed (Fig. 1). In a previous study, we found that the 9 -week weight of $M y k /+$ mice was less by $18.8 \%$ in males and $16.1 \%$ in females [10]. The smaller deficit of adult $M y k /+$ females in the present study could reflect a sex-specific response to differing husbandry conditions. Male heterozygous Atp $1 a 3^{\mathrm{D} 801 \mathrm{~N} /+}$ mice, which carry the most common mutation causing AHC (D801N), also show lower body weight at 8 and 9 weeks of age, but Atpla $3^{\text {D801N }}$ genotype had no effect on the body weight of female mice at any age [17].

\section{Balance beam}

Abnormalities of fine motor skills are present in the vast majority of AHC patients and become more evident with age [2, 18]. As a measure of motor coordination, we tested mice on a

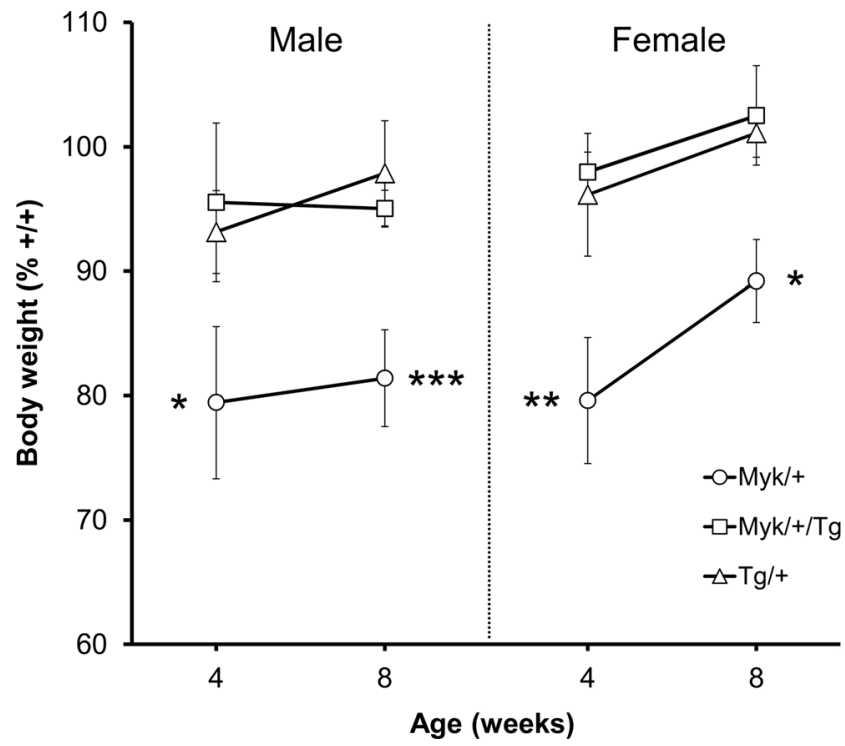

Fig. 1 Body weight ( $\%$ of $+/+$; mean \pm SEM) of male ( $n=6 /$ genotype) and female ( $n=6 /$ genotype) $M y k /+, M y k /+/ \mathrm{Tg}$, and $\mathrm{Tg} /+$ mice at 4 and 8 weeks of age. For body weight at 4 weeks, main effects of Atpla 3 genotype $(F(1,42)=8.41, p<0.01)$, sex $(F(1,42)=7.40, p<0.01)$, and Atpla3 genotype by $\mathrm{Tg}$ genotype interaction $(F(1,42)=12.69$, $p<0.001)$ were observed. For body weight at 8 weeks, main effects of Atpla3 genotype $(F(1,42)=14.18, p<0.001)$, Tg genotype $(F(1,42)=$ $8.84, p<0.01)$, sex $(F(1,42)=82.72, p<0.0001)$, and Atpla3 genotype by Tg genotype interaction $(F(1,42)=10.83, p<0.01)$ were observed. ${ }^{*} p<0.05 ;{ }^{* *} p<0.01 ; * * *<0.001$ compared with $+/+$ mice 
balance beam, which is useful for detecting subtle deficits in motor skills and balance that may not be detected by other motor tests, such as the rotarod [19]. At $24 \mathrm{~h}$ after training, $M y k /+$ mice showed a significantly greater number of hind foot slips than the other genotypes as they traversed the beam (Fig. 2a). Myk/+ mice also took longer than the other genotypes to traverse the beam (Fig. 2b). By contrast, the number of foot slips and the traversal time of $M y k /+/ T g$ mice were not significantly different from those of $+/+$ mice, as confirmed by the significant Atpla3 genotype by $\mathrm{Tg}$ genotype interactions observed (Fig. 2). Atpla $3^{\mathrm{D} 801 \mathrm{~N} /+}$ mice have also performed poorly in the balance beam test [17].

\section{Visible platform water maze}

Cognitive impairment has been observed in $94 \%$ [2] and $100 \%$ [1] of different AHC patient cohorts studied. The

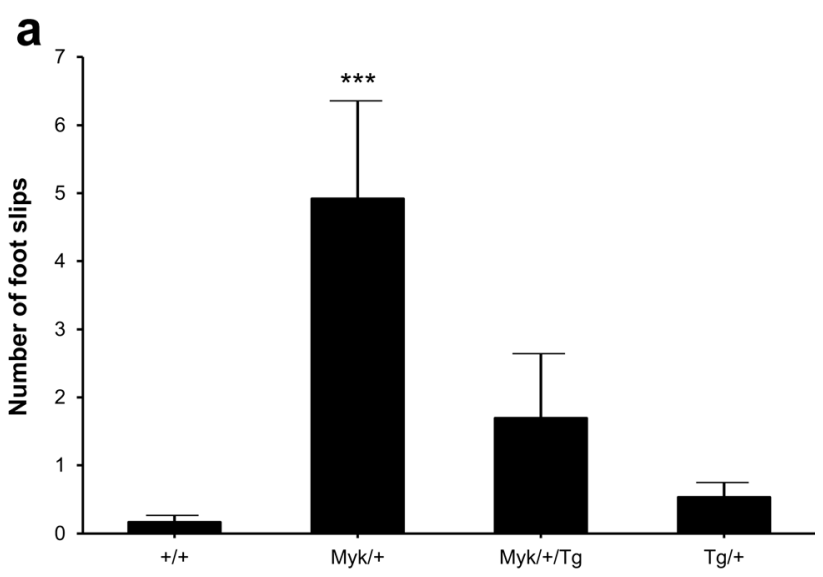

b

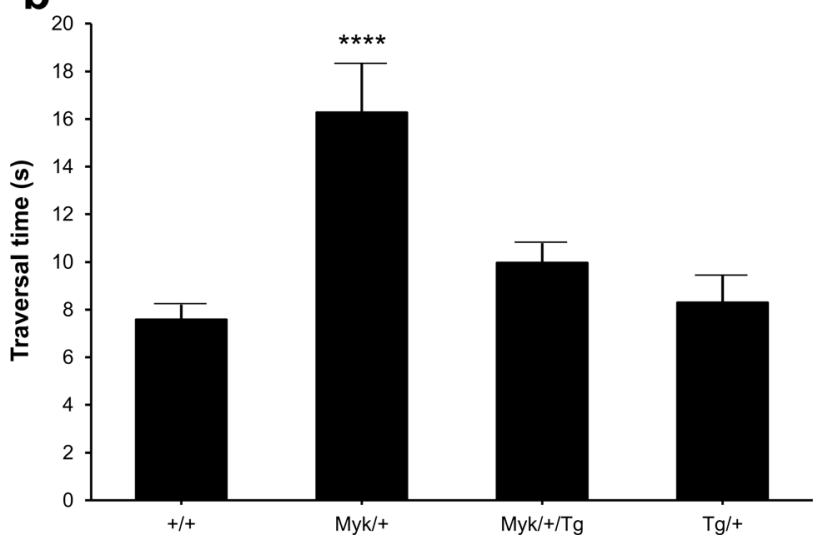

Fig. 2 Balance beam performance of $+/+, M y k /+, M y k /+/ T g$, and $\mathrm{Tg} /+$ mice ( $n=12 /$ genotype). a Number of hind foot slips (mean \pm SEM) and $\mathbf{b}$ traversal time $(\mathrm{s} ;$ mean $\pm \mathrm{SEM})$ when traversing a narrow beam. For the number of foot slips, main effects of Atpla3 genotype $(F(1,42)=14.11$, $p<0.001)$ and Atpla3 genotype by $\mathrm{Tg}$ genotype interaction $(F(1,42)=$ $5.02, p<0.05)$ were observed. For traversal time, main effects of Atpla3 genotype $(F(1,42)=22.19, p<0.0001), \operatorname{Tg}$ genotype $(F(1,42)=5.52$, $p<0.05)$, and Atpla3 genotype by $\mathrm{Tg}$ genotype interaction $(F(1,42)=$ 9.54, $p<0.01)$ were observed. $* * * p<0.001 ; * * * * p<0.0001$ compared with $+/+$ mice visible platform version of the water maze is a simple associative non-spatial task believed to be independent of hippocampal function [20]. This procedure introduces the mice to the main task requirements (e.g., swimming, the fact that the platform is not near the perimeter, and climbing on the platform to escape) and assesses whether they have the performance skills necessary for spatial memory to be assessed in the hidden platform task. In this rather stressful condition, mice are required to maintain sufficient behavioral flexibility to overcome their initial tendency to swim along the wall of the pool, an innate behavior called wall hugging or thigmotaxis [20]. Then, they must learn that they are returned to their warm home cage if they climb and stay on the escape platform indicated by a marker rising above the water.

Over four trials, only $+/+$ and $\mathrm{Tg} /+$ mice showed quick orientation toward the visually marked platform location. $M y k /+$ and $M y k /+/ T g$ mice took more time (Fig. 3a) and swam further (Fig. 3b) before reaching the visible platform. $M y k /+/$ $\mathrm{Tg}$ mice performed marginally better than $M y k /+$ mice, but the overall performance of both was poor, as confirmed by the lack of Atpla3 genotype by Tg genotype interactions for latency and path length. There were no significant differences between genotypes in swim speed and floating. The deficient performances of $M y k /+$ and $M y k /+/ T g$ mice were largely due to their excessive thigmotaxis (Fig. 3c), an effect of the I810N mutation not attenuated by the Atp $1 a 3^{1 \text { Stcl }}$ transgene. The mutation reduced behavioral flexibility to such a degree that $M y k /+$ and $M y k /+/ T g$ mice were practically unable to overcome thigmotaxis, as previously observed in mice with forebrain-specific knockout of the TrkB receptor [22]. Excessive thigmotaxis has also been observed in mice with retinal degeneration [23], but the normal head tracking of $M y k /+$ mice in an optokinetic drum suggests that their vision is not impaired [14].

Atpla $3^{\mathrm{D} 801 \mathrm{~N} / \mathrm{+}}$ mice have also performed poorly in the visible platform task [17]. Atpla $3^{\text {tm1Ling/+ }}$ mice were given four trials per day for 6 days, in which the visible platform position was changed at random on each trial. Atpla $3^{\text {tmlLing/+ }}$ mice took significantly longer to reach the visible platform on days $2-5$ but caught up to wild-type controls by day 6 [15].

\section{Contextual fear conditioning}

Contextual fear conditioning assesses a memory for the association between an aversive stimulus, such as a mild foot shock, and a salient environmental cue, the test chamber ("context"). Rodents with good memory have a natural tendency to freeze (suppress all movement) upon re-presentation of the context. Contextual fear conditioning is dependent upon the integrity of the hippocampus [24]. Baseline freezing, before the administration of a foot shock, was less than $3 \%$ for all genotypes, although the baseline freezing of $\mathrm{Tg} /+$ mice was significantly greater than that of $+/+$ and $M y k /+$ mice (Fig. 3d). 
a

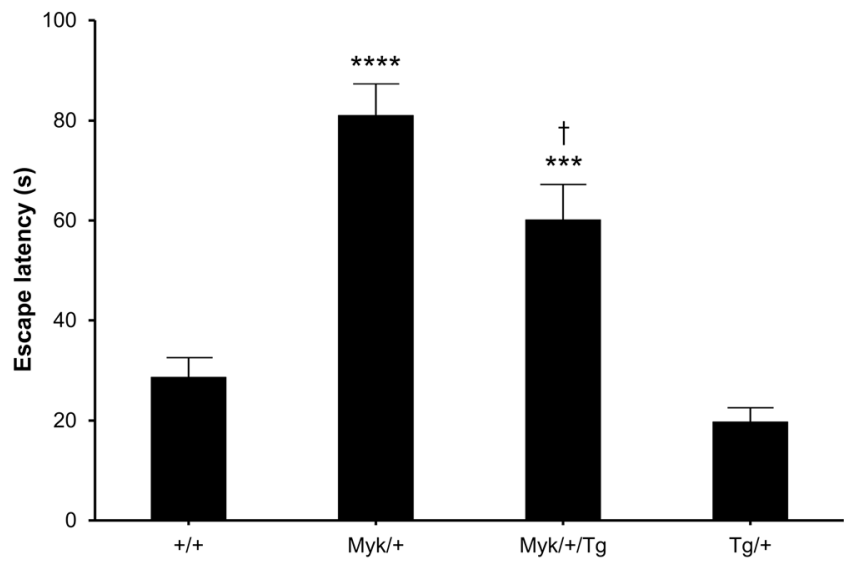

C

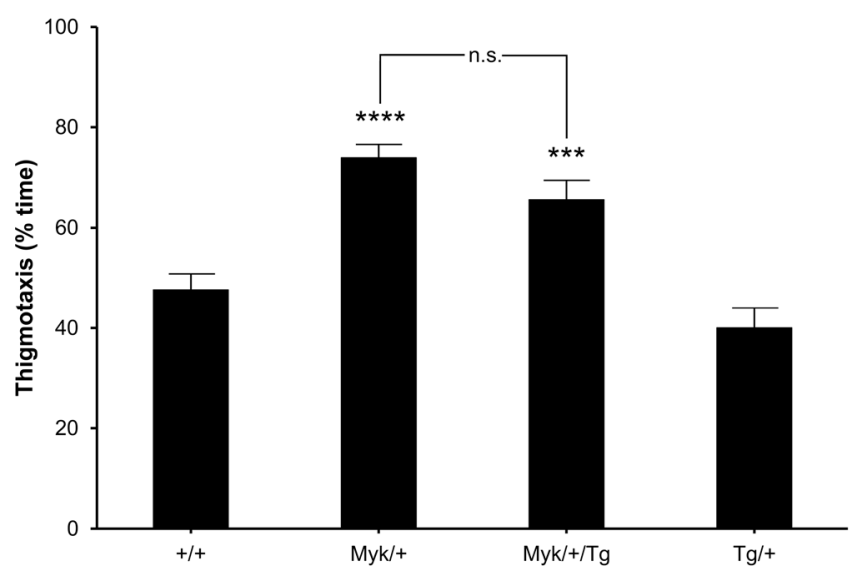

Fig. 3 Water maze and fear-conditioning performance of +/+, $M y k /+$, $M y k /+/ \mathrm{Tg}$, and $\mathrm{Tg} /+$ mice $(n=12 /$ genotype). a Escape latency (s; mean \pm SEM). Main effects of Atpla3 genotype $(F(1,42)=77.09, p<0.0001)$ and $\mathrm{Tg}$ genotype $(F(1,42)=7.79, p<0.01)$ were observed for latency. $\mathbf{b}$ Swim path length (m; mean \pm SEM). Main effects of Atpla3 genotype $(F(1,42)=67.20, p<0.0001)$ and $\mathrm{Tg}$ genotype $(F(1,42)=9.10, p<0.01)$ were observed for path length. c Thigmotaxis ( $\%$ time; mean \pm SEM). Main effects of Atpla3 genotype $(F(1,42)=53.10, p<0.0001)$ and $\mathrm{Tg}$ genotype $(F(1,42)=4.59, p<0.05)$ were observed for thigmotaxis. d Freezing levels (\% time; mean \pm SEM) of mice when test-naïve

At $24 \mathrm{~h}$ after receiving the foot shock, all genotypes increased their level of freezing compared with baseline, but $M y k /+$ mice showed a significantly lower level of contextual freezing than the other genotypes. By contrast, $M y k /+/ T g$ mice did not show any deficit in contextual fear conditioning, as confirmed by the significant Atpla3 genotype by Tg genotype interaction observed (Fig. 3d). Unlike Myk/+ mice, Atpla $3^{\mathrm{D} 801 \mathrm{~N} /+}$ mice have not shown any deficit in the formation of fear-related memories in the contextual fear-conditioning paradigm [17].

The clinical severity of AHC is extremely variable, but the rarity of the disorder has made it difficult to study genotypephenotype correlations. Nevertheless, the high frequency of D801N and E815K, responsible for most AHC cases, has allowed two independent studies to show that E815K causes a more severe phenotype than $\mathrm{D} 801 \mathrm{~N}$ with respect to age of b

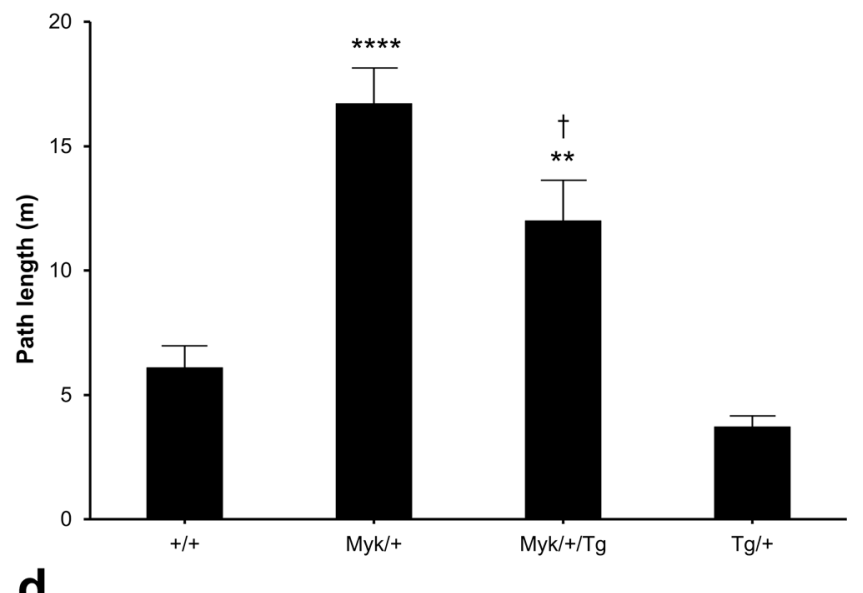

d

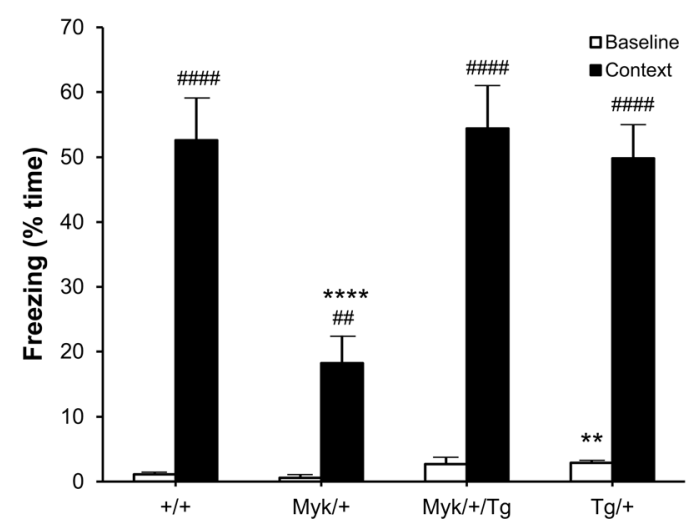

(baseline) and when returned to the chamber $24 \mathrm{~h}$ after training (context). For baseline freezing, a main effect of $\operatorname{Tg}$ genotype $(F(1,42)=11.60$, $p<0.01)$ was observed. For context freezing, main effects of Atpla3 genotype $(F(1,42)=5.33, p<0.05)$, Tg genotype $(F(1,42)=7.40, p<0.01)$, and Atpla3 genotype by Tg genotype interaction $(F(1,42)=10.01$, $p<0.01)$ were observed. ${ }^{* *} p<0.01 ; * * * p<0.001 ; * * * *<<0.0001 \mathrm{com}-$ pared with $+/+$ mice. $\dagger p<0.05$ compared with $M y k /+$ mice. \#\#p<0.01; $\# \# \# p<0.0001$ compared with baseline freezing for each genotype. n.s. not significant

onset, motor impairment, and a prevalence of status epilepticus $[25,26]$. Differences in mutant enzyme activity cannot account for the disease severity associated with E815K, since all of the AHC mutations that have been studied to date-S137Y, I274N, D801N, I810N, E815K, and G947R-were found to result in a catalytically inactive $\alpha 3$ enzyme [10, 13]. However, the recent finding that E815K, but not D801N and G947R, impairs the passive influx of protons into the cell [27] suggests that loss of proton transport is a correlate of severe AHC [28].

The isoleucine at position 810 is recurrently mutated in AHC [5-7], but I810N is one of the rarer mutations, having been found in only two cases to date: a 22-year-old male from Belgium with clinical features of episodic hemiplegia and dystonia triggered by emotional stress, mild ataxia with unstable gait, moderate intellectual disability and autism, and a clinical 
history of epilepsy with some episodes of status epilepticus [29]; and a 12-year-old Chinese male with clinical features of episodic hemiplegia, quadriplegia, abnormal eye movement, dystonia, epilepsy, and developmental delay [6].

Haploinsufficiency of ATP1A2 encoding the $\mathrm{Na}^{+}, \mathrm{K}^{+}$ATPase $\alpha 2$ subunit is associated with familial hemiplegic migraine type 2 [30], but recent functional analysis of $\alpha 3$ subunits suggests that an additional dominant-negative mechanism would contribute to loss of function in AHC [28]. Coexpression of wild-type and mutant $\alpha 3$ subunits (D801N, E815K, and G947R) in Xenopus laevis oocytes showed that mutant $\alpha 3$ subunits inhibit wild-type $\alpha 3$ function [28]. This dominant-negative effect may explain why the Tg-Atpla $3^{1 \text { Stcl }}$ transgene increased brain $\mathrm{Na}^{+}, \mathrm{K}^{+}$-ATPase activity in $M y k /+$ mice by only $16 \%$ [10]. Nevertheless, we have found that this modest increase in brain $\mathrm{Na}^{+}, \mathrm{K}^{+}$-ATPase activity was sufficient to rescue the phenotypic deficiencies of $M y k /+$ mice in body weight, motor coordination, and contextual fear conditioning. Increasing brain $\mathrm{Na}^{+}, \mathrm{K}^{+}$-ATPase activity to $80 \%$ of wild-type levels did not, however, rescue the deficient performance of $M y k /+$ mice in the visible platform version of the water maze, which is consistent with the deficient visible platform performance of Atpla $3^{\text {tmlLing/+ }}$ mice whose brain $\mathrm{Na}^{+}$, $\mathrm{K}^{+}$-ATPase activity is at $84 \%$ of wild-type levels $[14,15]$. In conclusion, our results show that a relatively small increase in $\mathrm{Na}^{+}, \mathrm{K}^{+}$-ATPase $\alpha 3$ activity has therapeutic effects in a mouse model of AHC. In light of these findings, interventions to increase the activity of wild-type $\mathrm{Na}^{+}, \mathrm{K}^{+}$-ATPase $\alpha 3$ in AHC patients should be investigated further.

Acknowledgments We thank the Centre for Modeling Human Disease (www.cmhd.ca) for producing the founder Myshkin mutant. This study was funded by the UK Medical Research Council (G0900625) and the Canadian Institutes of Health Research (MOP-94856).

Funding This study was funded by the UK Medical Research Council (G0900625) and the Canadian Institutes of Health Research (MOP94856). G.S.K. was supported by an Ontario Mental Health Foundation studentship. J.D. was supported by a Wellcome Trust Junior Investigator Development Fellowship. J.C.R. held a Canada Research Chair in Learning and Memory.

Compliance with Ethical standards All procedures involving animals were conducted in accordance with the Animals (Scientific Procedures) Act 1986 and were approved by the University of Leeds Ethical Review Committee. This article does not contain any studies with human participants performed by any of the authors.

Conflict of interest The authors declare that they have no conflict of interest.

Open Access This article is distributed under the terms of the Creative Commons Attribution 4.0 International License (http:// creativecommons.org/licenses/by/4.0/), which permits unrestricted use, distribution, and reproduction in any medium, provided you give appropriate credit to the original author(s) and the source, provide a link to the Creative Commons license, and indicate if changes were made.

\section{References}

1. Sweney MT, Silver K, Gerard-Blanluet M, Pedespan JM, Renault F, Arzimanoglou A, Schlesinger-Massart M, Lewelt AJ, Reyna SP, Swoboda KJ (2009) Alternating hemiplegia of childhood: early characteristics and evolution of a neurodevelopmental syndrome. Pediatrics 123:e534-41

2. Panagiotakaki E, Gobbi G, Neville B, Ebinger F, Campistol J, Nevsímalová S, Laan L, Casaer P, Spiel G, Giannotta M, Fons C, Ninan M, Sange G, Schyns T, Vavassori R, Poncelin D, ENRAH Consortium, Arzimanoglou A (2010) Evidence of a nonprogressive course of alternating hemiplegia of childhood: study of a large cohort of children and adults. Brain 133:3598-610

3. Heinzen EL, Arzimanoglou A, Brashear A, Clapcote SJ, Gurrieri F, Goldstein DB, Jóhannesson SH, Mikati MA, Neville B, Nicole S, Ozelius LJ, Poulsen H, Schyns T, Sweadner KJ, van den Maagdenberg A, Vilsen B, ATP1A3 Working Group (2014) Distinct neurological disorders with ATP1A3 mutations. Lancet Neurol 13:503-14

4. Benarroch EE (2011) Na+, K+-ATPase: functions in the nervous system and involvement in neurologic disease. Neurology 76:28793

5. Rosewich H, Ohlenbusch A, Huppke P, Schlotawa L, Baethmann M, Carrilho I, Fiori S, Lourenço CM, Sawyer S, Steinfeld R, Gärtner J, Brockmann K (2014) The expanding clinical and genetic spectrum of ATP1A3-related disorders. Neurology 82:945-55

6. Yang X, Gao H, Zhang J, Xu X, Liu X, Wu X, Wei L, Zhang Y (2014) ATP1A3 mutations and genotype-phenotype correlation of alternating hemiplegia of childhood in Chinese patients. PLoS One 9:e97274

7. Heinzen EL, Swoboda KJ, Hitomi Y, Gurrieri F, Nicole S, de Vries B, Tiziano FD, Fontaine B, Walley NM, Heavin S, Panagiotakaki E, European Alternating Hemiplegia of Childhood Genetics Consortium; Biobanca e Registro Clinico per l'Emiplegia Alternante Consortium; European Network for Research on Alternating Hemiplegia for Small and Medium-sized Enterprise Consortium, Fiori S, Abiusi E, Di Pietro L, Sweney MT, Newcomb TM, Viollet L, Huff C, Jorde LB, Reyna SP, Murphy KJ, Shianna KV, Gumbs CE, Little L, Silver K, Ptáček LJ, Haan J, Ferrari MD, Bye AM, Herkes GK, Whitelaw CM, Webb D, Lynch BJ, Uldall P, King MD, Scheffer IE, Neri G, Arzimanoglou A, van den Maagdenberg AM, Sisodiya SM, Mikati MA, Goldstein DB (2012) De novo mutations in ATP1A3 cause alternating hemiplegia of childhood. Nat Genet 44:1030-4

8. Ulate-Campos A, Fons C, Artuch R, Castejón E, Martorell L, Ozelius L, Pascual J, Campistol J (2014) Alternating hemiplegia of childhood with a de novo mutation in ATP1A3 and changes in SLC2A1 responsive to a ketogenic diet. Pediatr Neurol 50:377-9

9. Roubergue A, Philibert B, Gautier A, Kuster A, Markowicz K, Billette de Villemeur T, Vuillaumier-Barrot S, Nicole S, Roze E, Doummar D (2015) Excellent response to a ketogenic diet in a patient with alternating hemiplegia of childhood. JIMD Rep 15:712

10. Clapcote SJ, Duffy S, Xie G, Kirshenbaum G, Bechard AR, Rodacker Schack V, Petersen J, Sinai L, Saab BJ, Lerch JP, Minassian BA, Ackerley CA, Sled JG, Cortez MA, Henderson JT, Vilsen B, Roder JC (2009) Mutation I810N in the $\alpha 3$ isoform of $\mathrm{Na}+, \mathrm{K}+$-ATPase causes impairments in the sodium pump and hyperexcitability in the CNS. Proc Natl Acad Sci U S A 106: 14085-90

11. Kirshenbaum GS, Dawson N, Mullins JG, Johnston TH, Drinkhill MJ, Edwards IJ, Fox SH, Pratt JA, Brotchie JM, Roder JC, Clapcote SJ (2013) Alternating hemiplegia of childhood-related neural and behavioural phenotypes in $\mathrm{Na}+, \mathrm{K}+$-ATPase $\alpha 3$ missense mutant mice. PLoS One 8:e60141 
12. Kirshenbaum GS, Dachtler J, Roder JC, Clapcote SJ (2015) Characterization of cognitive deficits in mice with an alternating hemiplegia-linked mutation. Behav Neurosci. doi:10.1037/ bne0000097

13. Weigand KM, Messchaert M, Swarts HG, Russel FG, Koenderink JB (2014) Alternating hemiplegia of childhood mutations have a differential effect on $\mathrm{Na}+, \mathrm{K}+$-ATPase activity and ouabain binding. Biochim Biophys Acta 1842:1010-6

14. Kirshenbaum GS, Clapcote SJ, Duffy S, Burgess CR, Petersen J, Jarowek KJ, Yücel YH, Cortez MA, Snead OC, Vilsen B, Peever JH, Ralph MR, Roder JC (2011) Mania-like behavior induced by genetic dysfunction of the neuron-specific $\mathrm{Na}+, \mathrm{K}+-$ ATPase $\alpha 3$ sodium pump. Proc Natl Acad Sci U S A 108: 18144-9

15. Moseley AE, Williams MT, Schaefer TL, Bohanan CS, Neumann JC, Behbehani MM, Vorhees CV, Lingrel JB (2007) Deficiency in Na, K-ATPase alpha isoform genes alters spatial learning, motor activity, and anxiety in mice. J Neurosci 27:616-26

16. Neville BG, Ninan M (2007) The treatment and management of alternating hemiplegia of childhood. Dev Med Child Neurol 49: $777-80$

17. Hunanyan AS, Fainberg NA, Linabarger M, Arehart E, Leonard AS, Adil SM, Helseth AR, Swearingen AK, Forbes SL, Rodriguiz RM, Rhodes T, Yao X, Kibbi N, Hochman DW, Wetsel WC, Hochgeschwender U, Mikati MA (2015) Knock-in mouse model of alternating hemiplegia of childhood: behavioral and electrophysiologic characterization. Epilepsia 56:82-93

18. Bourgeois M, Aicardi J, Goutieres F (1993) Alternating hemiplegia of childhood. J Pediatr 122:673-9

19. Stanley JL, Lincoln RJ, Brown TA, McDonald LM, Dawson GR, Reynolds DS (2005) The mouse beam walking assay offers improved sensitivity over the mouse rotarod in determining motor coordination deficits induced by benzodiazepines. J Psychopharmacol 19:221-7

20. D'Hooge R, De Deyn PP (2001) Applications of the Morris water maze in the study of learning and memory. Brain Res Brain Res Rev 36:60-90

21. Wolfer DP, Lipp HP (2000) Dissecting the behaviour of transgenic mice: is it the mutation, the genetic background, or the environment? Exp Physiol 85:627-34

22. Minichiello L, Korte M, Wolfer D, Kühn R, Unsicker K, Cestari V, Rossi-Arnaud C, Lipp HP, Bonhoeffer T, Klein R (1999) Essential role for TrkB receptors in hippocampus-mediated learning. Neuron 24:401-14
23. Clapcote SJ, Lazar NL, Bechard AR, Roder JC (2005) Effects of the rd1 mutation and host strain on hippocampal learning in mice. Behav Genet 35:591-601

24. Holland PC, Bouton ME (1999) Hippocampus and context in classical conditioning. Curr Opin Neurobiol 9:195-202

25. Sasaki M, Ishii A, Saito Y, Morisada N, Iijima K, Takada S, Araki A, Tanabe Y, Arai H, Yamashita S, Ohashi T, Oda Y, Ichiseki H, Hirabayashi S, Yasuhara A, Kawawaki H, Kimura S, Shimono M, Narumiya S, Suzuki M, Yoshida T, Oyazato Y, Tsuneishi S, Ozasa S, Yokochi K, Dejima S, Akiyama T, Kishi N, Kira R, Ikeda T, Oguni H, Zhang B, Tsuji S, Hirose S (2014) Genotype-phenotype correlations in alternating hemiplegia of childhood. Neurology 82: 482-90

26. Viollet L, Glusman G, Murphy KJ, Newcomb TM, Reyna SP, Sweney M, Nelson B, Andermann F, Andermann E, Acsadi G, Barbano RL, Brown C, Brunkow ME, Chugani HT, Cheyette SR, Collins A, DeBrosse SD, Galas D, Friedman J, Hood L, Huff C, Jorde LB, King MD, LaSalle B, Leventer RJ, Lewelt AJ, Massart MB, Mérida MR, Ptáček LJ, Roach JC, Rust RS, Renault F, Sanger TD, Sotero de Menezes MA, Tennyson R, Uldall P, Zhang Y, Zupanc M, Xin W, Silver K, Swoboda KJ (2015) Alternating hemiplegia of childhood: retrospective genetic study and genotypephenotype correlations in 187 subjects from the US AHCF Registry. PLoS One 10:e127045

27. Vedovato N, Gadsby DC (2014) Route, mechanism, and implications of proton import during $\mathrm{Na}^{+} / \mathrm{K}^{+}$exchange by native $\mathrm{Na}^{+} / \mathrm{K}^{+}$. ATPase pumps. J Gen Physiol 143:449-64

28. Li M, Jazayeri D, Corry B, McSweeney KM, Heinzen EL, Goldstein DB, Petrou S (2015) A functional correlate of severity in alternating hemiplegia of childhood. Neurobiol Dis 77:88-93

29. Panagiotakaki E, De Grandis E, Stagnaro M, Heinzen EL, Fons C, Sisodiya S, de Vries B, Goubau C, Weckhuysen S, Kemlink D, Scheffer I, Lesca G, Rabilloud M, Klich A, Ramirez-Camacho A, Ulate-Campos A, Campistol J, Giannotta M, Moutard ML, Doummar D, Hubsch-Bonneaud C, Jaffer F, Cross H, Gurrieri F, Tiziano D, Nevsimalova S, Nicole S, Neville B, van den Maagdenberg AM, Mikati M, Goldstein DB, Vavassori R, Arzimanoglou A; Italian IBAHC Consortium; French AHC Consortium; International AHC Consortium (2015) Clinical profile of patients with ATP1A3 mutations in Alternating Hemiplegia of Childhood-a study of 155 patients. Orphanet J Rare Dis. 10:123

30. De Fusco M, Marconi R, Silvestri L, Atorino L, Rampoldi L, Morgante L, Ballabio A, Aridon P, Casari G (2003) Haploinsufficiency of ATP1A2 encoding the $\mathrm{Na}^{+} / \mathrm{K}^{+}$pump alpha2 subunit associated with familial hemiplegic migraine type 2. Nat Genet 33:192-6 